\title{
The Global Financial Crisis and the Chinese Economy: A Review of the Transmission Channels and Impacts
}

\author{
Cheejir $\mathrm{Wu}$ \\ Correspondence: Cheejir Wu, School of Economics and Finance, Mail box 367, Shanghai International Studies \\ University, 550 West Dalian Road, Hongkou District, 200083, Shanghai, China
}

\author{
Received: March 31, 2014 Accepted: April 15, 2014 Available online: May 2, 2014 \\ doi:10.11114/aef.v1i1.379 URL: http://dx.doi.org/10.11114/aef.v1i1.379
}

\begin{abstract}
In this study we present an analytical framework providing guidelines for discussions and expositions on the various possible transmission mechanisms of the impacts of the global crisis on the Chinese economy. While the crisis had discernible impacts on its finance, the main channels through which China felt the impacts were trade and trade related ones. One channel is related to the diversification of export markets. Moreover, trade is closely related to the financial system. The global crisis has affected the Chinese economy by triggering worsening conditions of the financial system. Also, foreign investment has played a crucial role after the hit of the global crisis. Still one more important channel is associated with the susceptibility of the economy to the shocks of foreign exchange rates.
\end{abstract}

Keywords: financial crisis, transmission channels, China, trade

\section{Introduction}

The year 2008 witnessed a historical record of the global financial crisis in the new century. The crisis had a sweeping effect on the world economy. For the first time since the early 1980s, the USA, the EU and Japan (G-3 economies) experienced a simultaneous severe economic recession. The leaders of several countries began considering the need for a "Bretton Woods II", in reference to the fundamental characteristics of the reforms that should be triggered by the crisis. Created after the East Asian financial crisis as a forum for broadening the discussion of international economic issues, the Group of 20 (G20), a grouping that involved several emerging market countries, was vested with a new mandate. The Heads of State of this group gathered in the US for an unprecedented G20 Summit for Financial Markets and the World Economy, which agreed upon "Principles" and an "Action Plan for Reform", followed by second and third rounds held in London and Pittsburgh (Caliari 2012). ${ }^{1}$

Like the other countries in the world, China was not immune to this pervasive recession. However, the Chinese government responded swiftly to the impacts of the global financial crisis by introducing a four trillion yuan stimulus package. Acting in tandem, the central bank cut the interest rates greatly, and the growth rates of credit and of broad money shot up. The stimulus package and the extremely accommodating monetary policy seem to have helped the economy start bottoming out as early as in the first quarter of 2009. However, it is still too early to see whether the economic recovery is sustainable or only temporary. To some degree, the recovery of the economy has been realized at the cost of worsening structural problems. It is therefore still too soon to judge whether the Chinese economy will be able to survive the crisis with a more balanced industrial structure and whether it will embark on a more sustainable development path (Yu 2010). As China is regaining momentum after the global financial crisis, it is important to ask how the global crisis has affected the Chinese economy and how effective China's responses were. Taking stock of such questions will provide important guidelines for preventing and tackling future crises.

The remainder of this paper proceeds as follows. Section 2 introduces the global background of the worldwide financial crisis, which serves as an overview of the general issue that motivates the present study. Section 3 presents a tentative theoretical framework that provides guidelines within which our subsequent discussions will be carried out. Section 4 discusses the transmission channels of the shocks of the global financial crisis and their impacts, either direct or indirect, on the Chinese economy. Section 5 summarizes the conclusions.

\footnotetext{
${ }^{1}$ See, for example, Caliari (2012) for more discussion.
} 


\section{The Global Background: An Overview}

Initially, the US subprime crisis, which exploded in 2007, impacted only the financial industry with repercussions within the borders of the US. However, the situation continued to deteriorate, with home prices continuing to plummet and subprime default rates continuing to climb. ${ }^{2}$ By September 2008, when a large number of financial giants experienced abysmal difficulties, the subprime crisis escalated into a financial crisis, leading to a worldwide financial turmoil. The global financial crisis exerted an immediate and enormous impact on the growth of the worldwide economy. By the end of 2008, most developed countries slumped into recession, and developing countries stagnated. There were no signs of a quick turnaround, and the situation even worsened in some countries ( $\mathrm{Li}$ and $\mathrm{Yu}$ 2010). Figure 1 displays the growth rates of the global industrial production index. The index fell, by 1 percent in September 2008, 9.6 percent in December, and down a further 12 percent in March 2009. Subsequent declines diminished, but were still over 10 percent. Developed economies exhibited even steeper falls, which were well above 14 percent in the first few months of 2009.

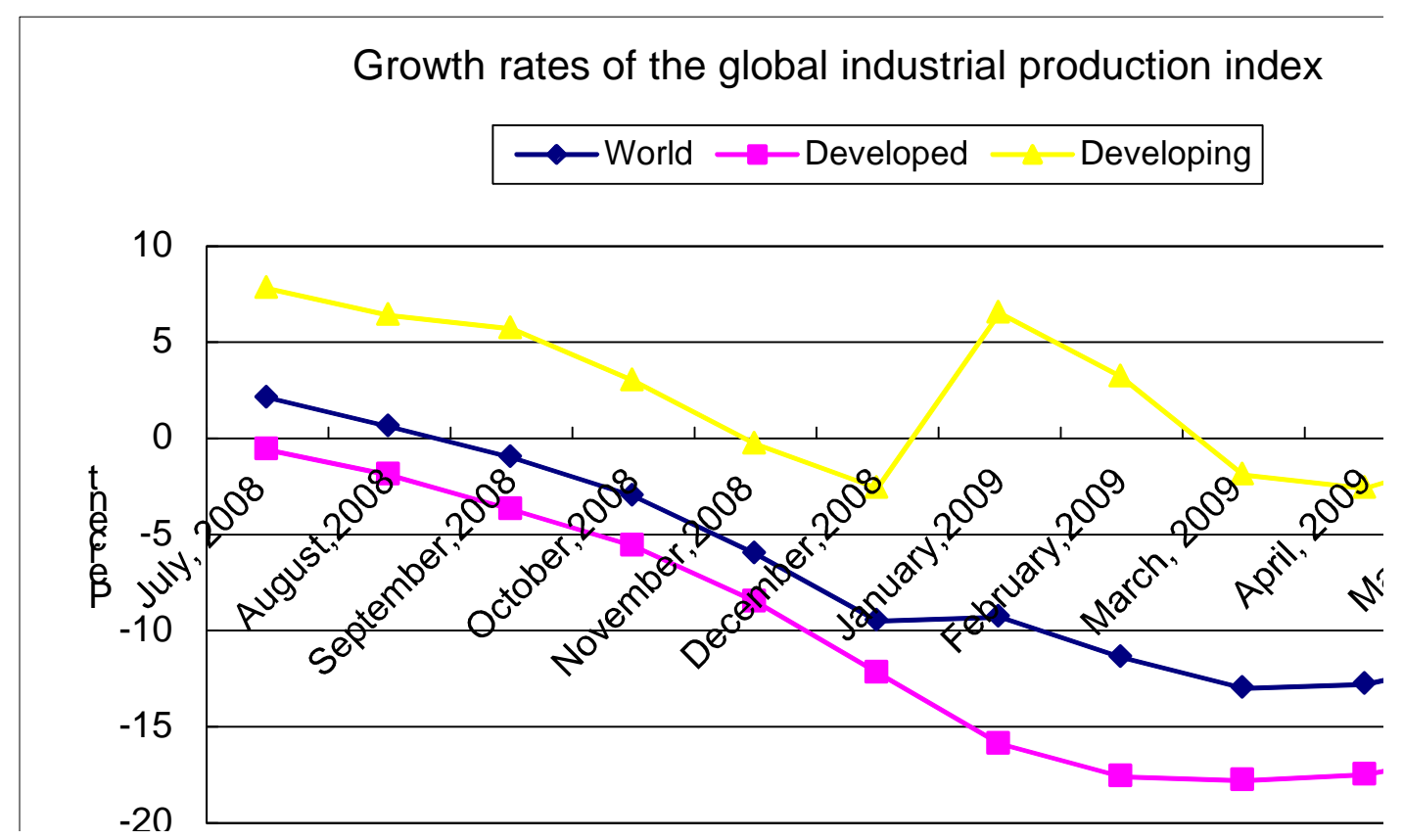

Data sources: (1) The International Information Center of National Bureau of Statistics; (2) World Bank Database.

Figure 1. Growth rates of the global industrial production index

Specifically, for the US, deep recession occurred. In the fourth quarter of 2008, the U.S. economy dropped by 6.4 percent in annual terms converted from the seasonally adjusted rate, which was the biggest fall since 1982, followed by a continued drop of 5.7 percent in the first quarter of 2009, forming a successive decline in three consecutive quarters. The shrinking of industrial production began to widen by a large degree after September 2008, down 6.3 percent on an annual basis. It further dropped by 6.8 percent in the fourth quarter of 2008, followed by continued monthly declines all exceeding 10 percent in the first six months of 2009. Figure 2 exhibits these trends. Besides the US, the economies of the euro zone and Japan were also seriously affected. In the fourth quarter of 2008, the euro zone and Japan dropped by 1.7 percent and 3.7 percent on a seasonally adjusted basis. The annual and seasonally adjusted decline rates of the euro zone were the largest since 1996. From the first quarter of 2009, the euro zone and Japan declined 2.5 percent and 3.8 percent, respectively, falling throughout four consecutive quarters. After the financial crisis, steep declines were also found in the growth rates of South Africa, Brazil, Russia, South Korea, Mexico, Hong Kong (region), Taiwan (region) and Malaysia, to name but a few. The quarterly rates of economic growth in selected countries are displayed in Figure 3.

\footnotetext{
2 The exposition in this section draws on relevant discussions of $\mathrm{Li}$ and $\mathrm{Yu}(2010)$.
} 


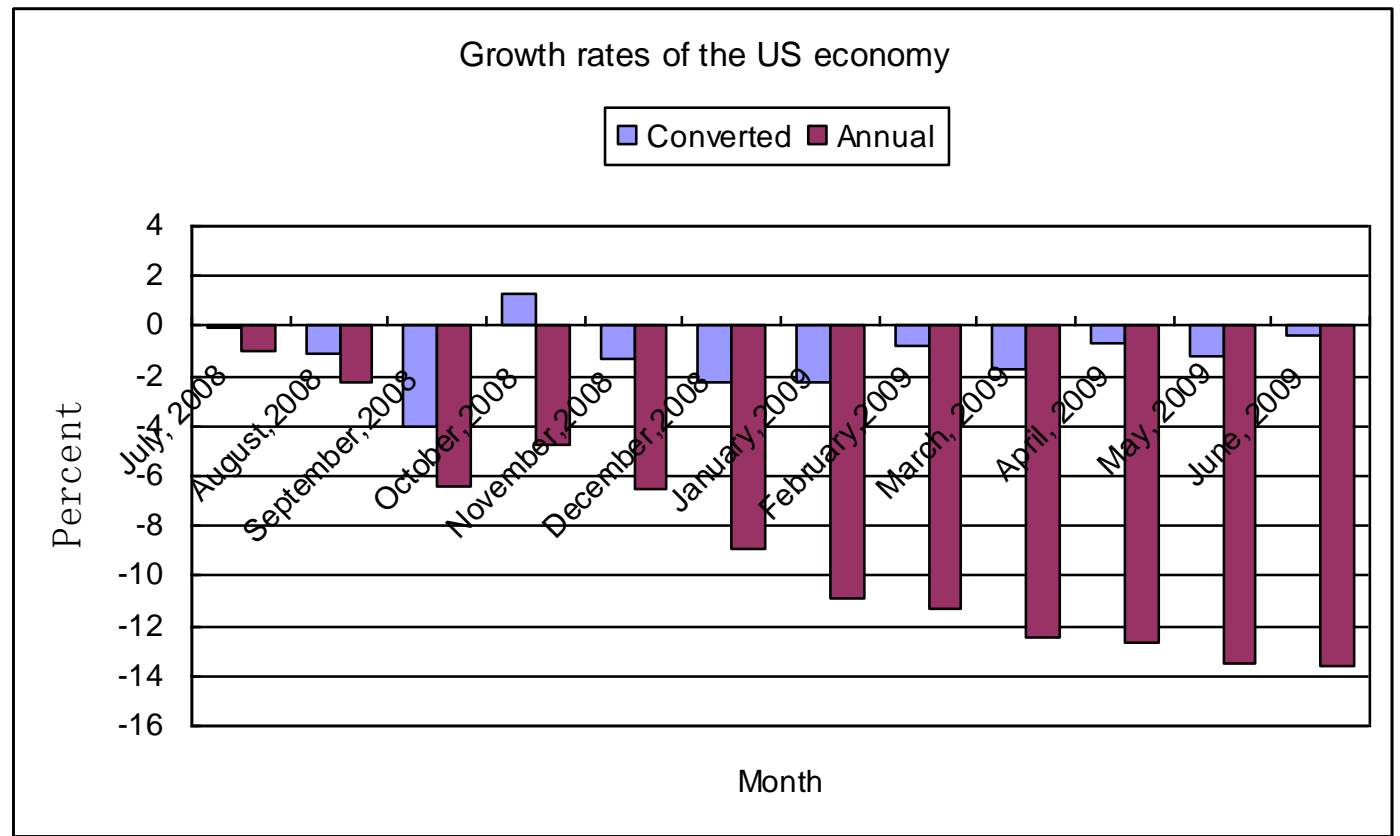

Data sources: (1) The International Information Center of National Bureau of Statistics; (2) World Bank Database. Figure 2. Growth rates of the US economy

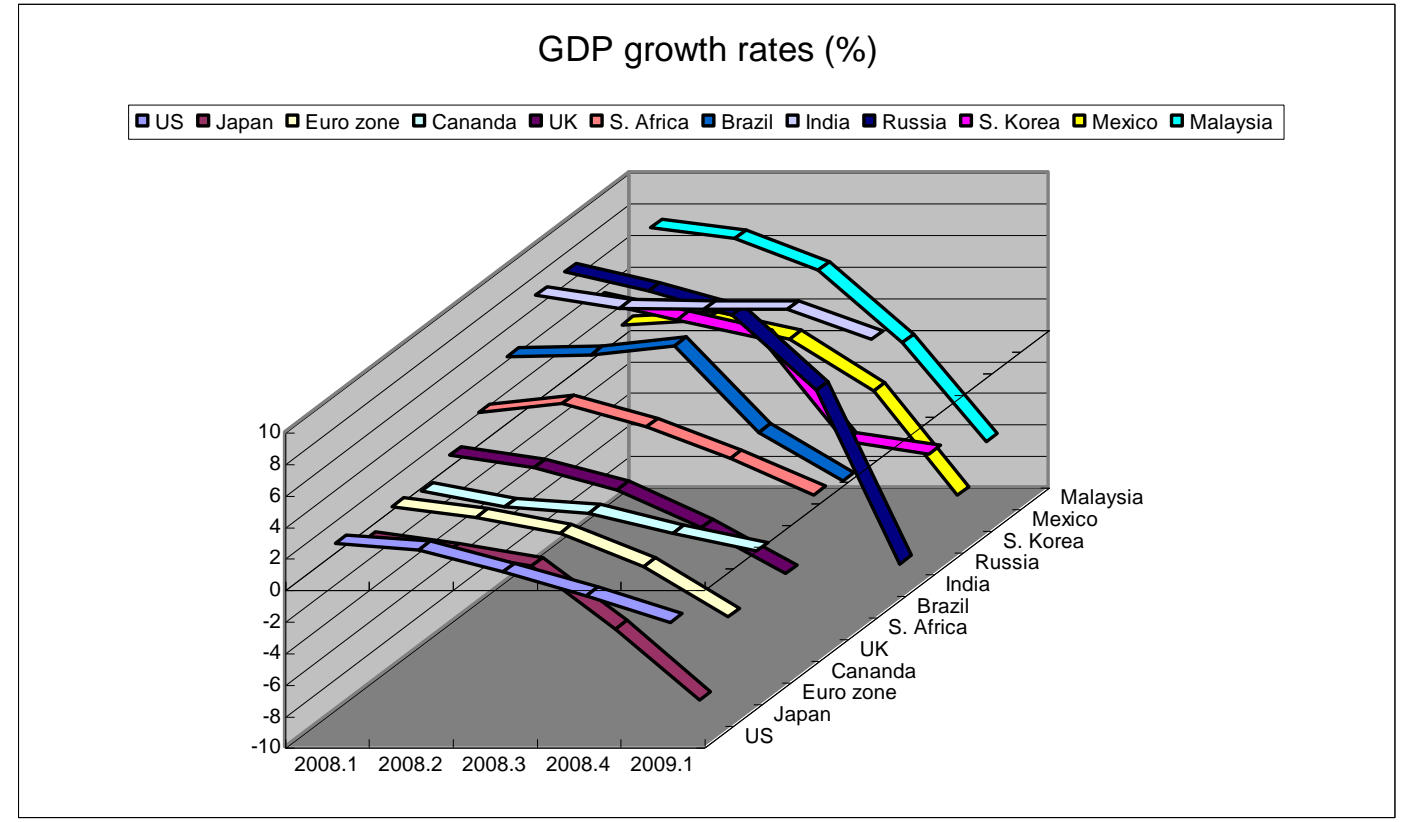

Data sources: (1) The International Information Center of National Bureau of Statistics; (2) World Bank Database.

Figure 3. Quarterly GDP growth rates in selected countries

Accompanying the output setbacks, unemployment rates are climbing in many countries. In September 2008, the unemployment in the US rose by 1.4 percentage points to 6.3 percent, compared with that at the beginning of the year, which continued to rise to 7.3 percent by the end of 2008, and then to 9.4 percent by June of 2009. Unemployment in the euro zone rose in a parallel fashion. It was 7.6 percent in September 2008, and rose to 9.7 percent by May of 2009. Employment in Japan was not hit that hard, but the unemployment rate still moved up from 3.9 percent in September 2008 to 5.5 percent in June $2009 .^{3}$

${ }^{3}$ Data sources: (1) World Bank Database; (2) The International Information Center of National Bureau of Statistics. 
As the global financial crisis exploded, volumes of foreign trade in many countries began to shrink sharply. Export growth rate in the US was 14.1 percent in the third quarter of 2008 but fell to 3.6 percent in the next quarter. In the first quarter of 2009, it dropped to a negative 16.8 percent, and fell further to a negative 21.4 percent during April and May. Import growth rate in the US dropped from 17.6 percent in the third quarter of 2008 to 7.8 percent in the fourth quarter. In the first quarter of 2009 , it dropped to a negative 27.3 percent, and fell further down to a negative 31.3 percent by May of 2009. The drops in exports and imports in the euro zone have been similar to those in the US, and Japan's declines in foreign trade were even larger. With the overall outbreak of the crisis, international commodity prices took a deep plunge too. The international energy price index, with a benchmark set at 100 in 2000, declined from 476.8 in June 2008 to 171.3 by the end of 2008, down 63.7 percent. Non-energy prices fell from 295.4 to 178.9 , down 39.4 percent. $^{4}$

The global financial crisis had a compelling impact all around the world, with major repercussions on private consumption, the credit market, the housing sector, as well as on public confidence ( $\mathrm{Li}$ and $\mathrm{Yu} \mathrm{2010)}$ ). Though the effects do not stop there, the four major affected areas demonstrated how serious the crisis was.

\section{An Analytical Framework}

To see the full impacts of the global financial crisis on the Chinese economy, responses from China, as well as policy implications for China, we need to set up an analytical framework to help us comb the various causes and effects.

One methodology is to explore the functions of trade, and especially exports, as well as other components of aggregate expenditure, through the demand side of the market. The study of the roles of the different components of aggregate expenditure in economic growth and development has always been extensively discussed. The different opinions on export-oriented growth, for example, for a big developing and transition economy (like China) are only one hot issue within these discussions. Based on the Keynesian theory, increases in the different components of aggregate expenditure are the various factors that will eventually lead to an increase in the level of aggregate output. Although some researchers argue that the major constraints of modern growth in developing countries reside in the supply side, rather than in the demand side of the economy, ${ }^{5}$ there are still many proponents of the demand-oriented approach who believe that major constraints of modern growth lie on the demand side, instead of on the supply side of the economy. ${ }^{6}$

The demand-oriented methodology generally starts with the Keynesian macroeconomic equilibrium condition. That is, in equilibrium the following condition must hold ${ }^{7}$

$$
Y=C+I+G+(X-M)
$$

where $Y, C, I, G, X$ and $M$ represent aggregate output, total consumption, total private investment, total government purchases, total exports and imports. Equation (1) implies

$$
g_{Y}=S_{C} \cdot g_{C}+S_{I} \cdot g_{I}+S_{G} \cdot g_{G}+S_{N X} \cdot g_{N X}
$$

where $N X$ (net exports) is defined as $N X \equiv X-M$. are the growth rates of the corresponding variables are denoted $g_{Y}$, $g_{C}, g_{V}, g_{G}$ and $g_{N X}$ and $S_{C}, S_{I}, S_{G}$ and $S_{N X}$ are the shares of total consumption, total private investment, total government purchases, and total net exports to aggregate output. The last term on the right-hand side of (2) is usually taken as the part of GDP growth that is attributable to growth in net exports. In many empirical studies, this last term on the right-hand side of (2) is generally considered a measure of the impact of exports on growth. However, this measure actually only takes account of only the direct effect of net exports on output growth, which it totally ignores the indirect effects of net exports on output via the former's impacts on domestic consumption, investment, and government purchases.

As many empirical studies using the demand-oriented methodology have this drawback, they give unrealistically low

${ }^{4}$ Data sources: (1) World Bank Database; (2) The International Information Center of National Bureau of Statistics.

${ }^{5}$ See, for example, McCombie and Thirlwall (1994) for a possible explanation of the popularity of this viewpoint, which is actually related to the remnant of Say's Law in people's mind. See also Lin and Li (2001).

${ }^{6}$ Just as Kaldor (1972) stated, "contrary to the traditional view which attributed the rate of industrial development in England to the rate of saving and capital accumulation and to the rate of technical progress due to invention and innovation, more recent evidence tends to suggest that Britain's industrial growth was 'export-led' from a very early date." Kaldor also pointed out that, "there can be little doubt that throughout the nineteenth century and also in the present century, right up to the Second World War, Great Britain's economic growth was closely dependent on the growth of her export. Given the fact that her share of the world market was bound to decline continually. ... It was quite inevitable that both the growth of production and the accumulation of capital should be much lower in Britain than in the countries that were subsequently industrialized." See also Lin and $\mathrm{Li}$ (2001).

${ }^{7}$ See, for example, Lin and Li (2001). See also Zhang and Hu (1999) and Abdulai and Ramcke (2009). 
estimations of the contribution of exports to GDP growth. Estimations based on the demand-oriented Keynesian equilibrium find that the contribution of exports to China's economic growth was only very marginal. Some researchers even find a negative relationship between China's exports and its GDP growth. As Lin and Li (2001) have rightly argued, the "discovery" of the negative relationship between net exports and output level (or growth) has challenged the theoretical foundation of the estimation method. According to the Keynesian model, the equilibrium output level must equal the sum of consumption, investment, government purchases and net exports. This is to say that net exports and GDP should be positively related. Therefore, one possible explanation to the observed negative relationship is the correlation between the different components of the aggregate expenditure. For instance, an increase in investment or in autonomous consumption may lead to an increase in imports and consequently a decrease in net exports while GDP as a whole still increases. ${ }^{8}$

To solve the problem mentioned above, we consider the following relationship

$$
\begin{gathered}
Y=\beta_{Y 0}+\beta_{Y 1} N X+\varepsilon_{Y} \\
C=\beta_{C 0}+\beta_{C 1} N X+\varepsilon_{C} \\
I=\beta_{I 0}+\beta_{I 1} N X+\varepsilon_{I} \\
G=\beta_{G 0}+\beta_{G 1} N X+\varepsilon_{G}
\end{gathered}
$$

which takes into consideration the indirect effects of net exports on aggregate output through consumption, investment as well as government purchases. Therefore, eventually, the ultimate total effect of net exports on national income, which in turn implies the net impact of the shocks of the global financial crisis on the Chinese economy through the trade channels, can then be reduced to a simple regression form as

$$
Y=\beta_{0}+\beta_{1} N X+\varepsilon
$$

where $\beta_{0}, \beta_{1}$ and $\varepsilon$ are the sums of the corresponding terms in (3).

Given this discussion, we shall bear in mind that the trade impacts of the shocks originated from the global financial crisis may be realized either through the direct effects of exports and imports or through various indirect effects of trade via the other components in the income-expenditure equation. The linkage between trade and national income can be captured by Figure 4 as follows.

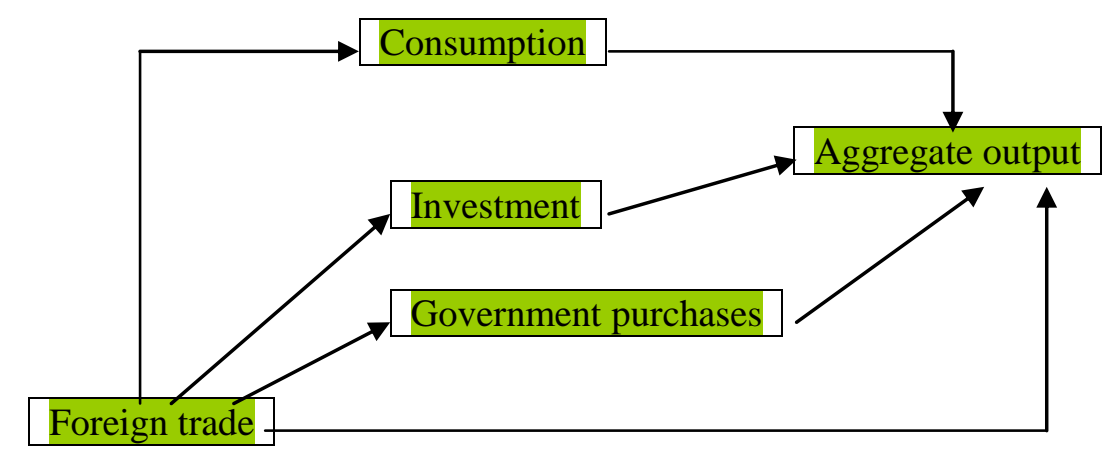

Foreign trade has not only a direct impact on aggregate output, but also indirect impacts on the latter through consumption, investment and government purchases.

Figure 4. Potential channels of impacts of trade on aggregate output

\section{Transmission Channels and Impacts of the Crisis}

There are basically three transmission mechanisms through which the global financial crisis impacted on the Chinese economy. ${ }^{9}$ One transmission mechanism of the crisis' shock is the direct losses in the American capital market. Before the subprime crisis, commercial banks in China had bought a moderate amount of mortgage-backed securities and

\footnotetext{
${ }^{8}$ See also Zhang and Hu (1999) and Abdulai and Ramcke (2009).

${ }^{9}$ See, for example, $\mathrm{Yu}$ (2010) for a detailed discussion of the four transmission mechanisms as well as supporting data.
} 
collateralized debt obligations. The total loss suffered by China's four most important commercial banks on these securities was estimated to be twenty billion US dollars. There is no comprehensive data available on the losses on the mortgage-related bonds held by China's commercial banks. The book losses of China's holdings of foreign exchange reserve were also moderate. In sum, compared with Eastern European countries and the developed economies, the direct losses of China in financial assets as a result of the US subprime crisis were estimated to be quite limited.

A second transmission mechanism of the economic shocks from the global financial crisis is associated with fluctuations in cross-border capital flows. Soon after the outbreak of the US subprime crisis, debates began to mushroom about whether international capital would flow into or out of China. Theoretically speaking, international capital can only flow into and out of the Chinese borders in the forms of foreign direct investment (FDI), officially approved foreign borrowing, as well as portfolio investment by qualified foreign and domestic institutional investors. One side of the debates argues that given China's strong economic performance, international capital would flow into China for a safe haven. However, the other side of the debates believes that owing to the liquidity shortage and the need for capital injection and deleveraging, international investors would liquidate their holdings in emerging markets, so that international capital would flow out of China and reenter the financial centers of developed economies. However, although China, like other developing economies, was impacted by the pro-cyclical cross-border capital flows, yet thanks to its capital controls and huge foreign exchange reserves, China did not suffer from erratic changes in the yuan exchange rate. In sum, China's capital controls raised the transaction costs of the movement of speculative capital flows and have thus substantially reduced the negative impacts of the global financial crisis on the macro stability of the Chinese economy.

Another transmission mechanism is associated with China's foreign trade. Compared with other economic aspects, the far more serious effect of the global financial crisis on China's economy was on its foreign trade. Data show that the most critical underlying cause for the fall of China's economic growth was the sudden slump of the export market. Of all the Chinese industries, the most dramatic fall in production occurred in the steel industry, where it can be seen from data that a serious drop in steel exports may have accounted for over 50 percent of the entire reduction in production in the steel industry, and the fall in exports was in itself a direct result of the global economic downturn. In sum, the dramatic fall in export demand was the most important cause for China's economic slowdown. The slowdown in fixed assets investments was also an important contributing factor for China's economic slowdown. However, the slowdown in fixed assets investments can in turn be (partly) attributed to the fall in export-related investments. ${ }^{10}$

The global financial crisis had a sweeping effect on the Chinese economy. However, while much of the attention to designing responses to the global financial crisis was on financial measures, the trade dimensions of the crisis were likely to be overlooked. For a big developing country like China, while the crisis had undeniably discernible impacts on its finance, the main channels through which China felt the impacts were trade and trade related ones. Not surprisingly, China, as a big developing country opening up and in transition, its dependence on foreign trade (as can be measured by its trade to GDP ratio) has been increasing over the decades. Worldwide, decades of reform in developing countries have placed the export led growth mode as the central paradigm. The characteristics and patterns of trade and the roles it played in the economies during the booms and recessions have generated two observations. One is that an emphasis on an improved export performance without a matching emphasis on the channels via which export increases would yield stable economic growth is of a very limited use. Another is that the success of trade led growth hinges not much on market access or trade policy reform per se, but rather on redrawing the roles of trade in developing economies and their relations to internal and external financial structures in these economies.

A major trade related channel via which a developing country may have suffered the global crisis was its narrow diversification of export products and markets. This explains the strong impact of the fall in commodity prices. As the crisis hit, a scenario of lower demand prevailed everywhere. The shortage of trade credit worsened the situation, as integration in global production chains is the common expression of the export led mode in manufacturing in developing countries. The limited diversity of products was not the only issue that confronted the developing countries, but also that of markets. Owing to the high degree of concentration of export markets, developing countries tend to be very susceptible to a slump in the markets of the developed countries. Even in Asia, where there was apparently a large share of South-South trade, there was still a need to look beneath the surface to see that a substantial part of the South-South trade was trade in parts for products that were ultimately exported to Northern markets. This means that the chain ultimately reaches the Northern markets, and therefore, the shrink in demand from these Northern markets had a worsening effect.

In addition, the pattern of foreign trade in developing countries tends to interact with the financial system. The global crisis triggered worsening conditions of the international financial system that tended to make the situation extremely

${ }^{10}$ For more detailed discussions, see, for example, Yu (2010). 
difficult for developing countries to escape from. As pointed out by Krugel (2008), the conditions of the financial system were generating real changes in the production and export process of most developing countries. Such changes were not long lasting and they tended to result in disruption when they were reversed. In particular, the bubbles in commodity prices were reflected in what should be considered bubbles in real exchange rates across countries. Therefore, it is critical to the trade welfare of developing countries that the volatilities of such prices receive adequate treatment through careful regulation.

One factor that boosted the developing economies before the hit of the global crisis was foreign direct investment, most of which was tied, in more or less direct ways, to the high speeds of export growth in China and other developing countries. Right after the crisis, reforms to foreign investment systems in China and other developing countries were introduced in the hope to promote and attract investment flows that would bolster growth and development. However, the rapid shift in investment projections during the crisis-affected period proved to reaffirm that foreign investment was attracted by high levels of growth rather than being the cause of the latter. From a neutral balance of payments perspective, attracting more foreign investment can hardly be considered always salutary to the economy because foreign investment tended to produce a pro-cyclical effect for the balance of payments by coming in good times and leaving in bad times.

The global financial crisis also increased the volatilities of foreign exchange rates. ${ }^{11}$ For China and other developing countries, one crucial role of foreign trade was arguably related to the susceptibility of the economy to the shocks of foreign exchange rates. The volatilities of the currency had important impacts on the competitiveness of firms (Dobbs et. at. 2009). This evidence is consistent with observations about the difficulties that exchange rate volatilities posed for the assessment of competitive advantages, the viability of domestic investment channeled to exports, and the costs of financial support to for export-oriented firms in China and other developing countries (Kotte 2009).

\section{Concluding Remarks}

The year 2008 saw a historically record-high level of the global financial crisis in this new millennium. The world economy felt a sweeping effect of the crisis. Like the other countries in the world, China was by no means immune to the pervasive recession triggered by the crisis. Despite the various swift measures taken by the Chinese government to counteract the negative effects of the global crisis, which included the stimulus package and the extremely accommodating monetary policy that seemed to have helped the Chinese economy start to bottom out, it is still too soon to conclude that the seeming recovery was sustainable or only short-lived. While China is regaining momentum after the global financial crisis, it is still unknown whether the Chinese economy will eventually survive the global crisis with a more balanced industrial structure and embark on a healthier path of sustainable development.

In the study of this paper, we first introduced the reader to the global background of the worldwide financial crisis, which served as an overview of the general issue that motivated and informed the central study of this paper. We then presented a tentative analytical framework that attempted to provide guidelines within which our later discussions and expositions were carried out. We also held discussions concerning the transmission channels of the shocks of the global financial crisis and their impacts, either direct or indirect, on the Chinese economy.

We have distinguished several transmission mechanisms through which the global financial crisis impacted on the Chinese economy. One transmission mechanism of the crisis' shocks is the direct losses in the American capital market. Another transmission mechanism of the economic shocks from the global financial crisis is linked to fluctuations in cross-border capital flows. A third transmission mechanism is associated with China's foreign trade. Compared with other economic aspects, the far more serious effect of the global financial crisis on China's economy was on its foreign trade. Data have revealed that the most crucial underpinning cause for the fall of China's economic growth was the sudden slump of the export market, which empirically justifies the application of our theoretical framework to the discussions in the present study.

Through our discussions, we have seen that for a big developing country like China, while the crisis had undeniably discernible impacts on its finance, the main channels through which China felt the impacts were trade and trade related ones. One major trade related channel via which a China may have suffered the global crisis was its limited diversification of export products and markets. Moreover, the pattern of foreign trade in China seems to be intertwined with its financial system. The global crisis affected the Chinese economy by triggering worsening conditions of the international financial system that tended to make the situation extremely difficult for developing countries to elude. Still, foreign investment seemingly played a role in helping China regain its momentum after the hit of the global crisis. Right after the crisis, reforms to foreign investment systems in China and other developing countries were introduced in expectation to facilitate and attract investment flows that would boost economic growth and development. The global

${ }^{11}$ For more detailed discussions, see, for example, Dobbs et. at. (2009), Kotte (2009), Yu (2010), and Li and Yu (2010). 
financial crisis also increased the volatilities of foreign exchange rates. For China and other developing countries, one more important effect of foreign trade was associated with the susceptibility of the economy to the shocks of foreign exchange rates. All of the mechanisms discussed in the current paper deserve further attention in future studies.

\section{References}

Abdulai, A., \& Ramcke, L. (2009). The Impact of Trade and Economic Growth on the Environment: Revisiting the Cross-Country Evidence, Kiel Working Paper No. 1491, Kiel Institute for the World Economy, March 2009.

Caliari, A. (2012). Trade Dimensions in the Impact of the Global Financial Crisis in Developing Countries: Are the Policy Responses Overlooking Them? in The Global Economic Crisis and the Developing World, Ashwini Deshpande and Keth Nurse (eds), Routledge, 2012.

Dobbs, R., Skilling, D., Hu, W., Lund, S., Manyika, J., \& Roxburgh, C. (2009). An Exorbitant Privilege? Implications of Reserve Currencies for Competitiveness, Discussion Paper, Mckinsey Global Institute.

Kaldor, N. (1972). Capitalism and Industrial Development: Some Lessons from Britain's Experience, in Kaldor, N., Further Essays on Applied Economics, Holmes \& Meler Publishers, Inc, 1978.

Kotte, D. (2009). Contribution in A. Caliari and V. P. Yu (eds), Trade and Finance Linkage for Promoting Development, Geneva, Center of Concern, South Center and German Marshell Fund.

Krugel, J. (2008). Systemic Issues: Background Document, Paper Presented at ECLAC Consultation in Preparation for the Financing for Development Review Conference, Santo Domingo, Dominican Republic, June.

Li, P., \& Yu, G. (2010). Regulatory Intervention Rescued China from the Impact of Global Financial Crisis, China Economist, 5, 1-16.

Lin, Y., \& Li, Y. (2001). Export and Economic Growth in China: A Demand-oriented Analysis, China Economic Quarterly, 2(4), 779-794.

McCombie, J., \& Thirlwall, A. (1994). Economic Growth and the Balance of Payments constraint. London, St. Martins.

Yu, Y. (2010), The Impact of the Global Financial Crisis on the Chinese Economy and China's Policy Responses, Third World Network Series 25.

Zhang, X., \& Hu, J. (1999). Behind Free Trade: Import and China's Economic Development, Intertrade, April 1999. Vol. 208.

\section{(cc) $\mathrm{Br}$}

This work is licensed under a Creative Commons Attribution 3.0 License. 